\title{
P-HRM: The Combination of PM and HRM
}

\author{
Gürhan Uysal \\ Ondokuz Mayıs University, Samsun, Turkey
}

\begin{abstract}
Personnel HRM is the combination of personnel management (PM) and human resource management (HRM). PM continues to be used in firms as an administrative function. HRM takes over the responsibilities of PM. HRM currently implements HRM practices in organizations. They are, for example, training, compensation, recruitment, careers, and others. There are two kinds of responsibilities of HRM departments in organizations: employee affairs and HR-related activities. Employee affairs are related with administrative functions. HRM has the mission of performance, both individual and firm. Wright and McMahan (1992) articulated that HRM is the relation between HRM practices and firm performance. On the other hand, Boston Consulting Group (2010) specified that the future of HRM might be talent management. Therefore, firms may apply personnel HRM in their structure, which is related with the application of PM and HRM together. Firms might have specialists (experts) for administrative functions, and experts for HRM-related practices. Therefore, personnel HRM is: Personnel HRM = PM + HRM or P-HRM = Administrative function + HRM practices. Firms have specific task person for these roles above.

Keywords: P-HRM, human resource management (HRM), personnel management (PM), HRM department, HR professionals
\end{abstract}

\section{Introduction}

This paper discusses the relation between PM and HRM. It is the relation of PM and HRM, and called as personnel HRM, i.e., P-HRM. This paper aims to increase the efficiency of HRM practices in firms. HR managers, HR professionals, HRM practices, and HRM departments are crucial to the efficiency of HRM practices in firms.

\section{Theoretical Background}

PM is related with job performance, and HRM is related with employee performance. There might be a viewpoint difference between PM and HRM. Employees are intellectual capital in HRM, who contribute to achieving a firm's objectives. PM is related with organizational jobs. Jobs are finance, marketing, accounting, production, supply, logistics, and others. PM advises personnel that those jobs must be implemented.

Personnel HRM is the combination of PM and HRM. PM continues to be applied in firms as an administrative function. On the other hand, HRM field takes over the responsibilities of PM. HRM departments currently implement HRM-related activities in organizations. They are, for example, training, compensation, recruitment, careers, and others. There are two kinds of responsibilities of HRM departments in organizations: employee affairs and HR-related activities. Employee affairs are related with administrative functions.

Gürhan Uysal, associate professor, School of Business, Kurupelit Campus, Ondokuz Mayıs University. Email: gurhan.uysal@yahoo.com. 
HRM has the mission of performance, both individual and firm, since the 1990s. Wright and McMahan (1992) articulated that HRM is the relation between HRM practices and firm performance. On the other hand, Boston Consulting Group (2010) specified that the future of HRM might be talent management. So, there may be two dimensions of HRM: performance and talent management. Therefore, firms may apply performance-oriented HRM and talent management in their structure. Firms may apply personnel HRM in their structure, which is related with the application of PM and HRM together. Firms might have specialists (experts) for administrative functions, and experts for HRM-related practices. Therefore, personnel HRM is: personnel HRM = PM + HRM and personnel HRM: administrative function + HRM practices. Firms must have specific task person for these roles above.

\section{Case Study}

Supposing Kontrax International has 300 employees and its HRM department operates with five task personnel. A new manager is appointed for the department, whose name is Michelle. Michelle reorganized the department. Victor becomes responsible for employee affairs, i.e., for administrative function, because legal obligations create much more workload for department. In European HRM, contextual perspective is necessary. Two others, Young and Mark, are handling HRM practices mission.

The strategic plan of departments is developed by top management and board of directors. Michelle plans the activities of HR department through daily meetings. The team argues the operations of the department. This company implements P-HRM as above.

\section{Discussion}

This paper discusses personnel HRM. It is the combination of PM and HRM. Firms currently apply employee affairs and performance in HRM. Talent management is another variable of HRM. Employee affairs take enormous time of HR professionals and HRM aims to increase the performance of employees. Since 1990, HRM has performance target: firm performance and individual performance. Today, HRM is also interested in talent management. Thus, HRM currently has two dimensions: performance and talent. Therefore, HRM departments in firms implement both employee affairs and performance improvement.

Furthermore, PM existed in firm management until the 1970s. HRM started discussion in the 1960s. At the beginning, it is identified with resource management and human resource administration. HRM takes over PM practices such as training, compensation, career, performance evaluation, recruitment, and others. Scholars, such as Schuler, Jackson, Devanna, Brewster, Sparrow, Guest, Huselid, Becker, Scott Snell, Delery, and others, build the discipline of HRM during the 1980s and the 1990s. Currently, PM continues as employee affairs in firms. It is daily activity. Thus, firms currently operate PM and HRM together in firm structure as employee affairs and performance. Therefore, this notion may be named as personnel HRM. Personnel HRM is the application of PM and HRM together in firm structure. It is employee affairs and performance focus. HRM departments currently implement HRM practices for performance. HRM practices aim to increase employee performance. In addition, employee performance may have an impact on firm performance subsequently. Further, HRM departments currently implement employment-related issues, which may be identified as employee affairs. Employee affairs take most time of HR professionals in firms. Thus, it needs specific task person. Personnel HRM combines those two concepts with the above notion: employee affairs and performance. Academics timely add talent figure to performance figure in HRM field. Therefore, firms may have specialists for employee affairs, and for HRM practices, performance focus and talent organization. 
Furthermore, this study assumes that HRM is the continued discipline of PM. PM departments were established in organizations during the 1930s. HRM concept started to be applied in the 1970s and the 1980s. HRM took over employees' responsibilities of PM. However, PM exists in organizations as employment-related issues. Therefore, personnel HRM concept might be applied in firms as PM and HRM. Finally, personnel HRM has employee affairs and performance improvement orientation. The aim of HRM is efficiency. The major sign of efficiency might become performance, individual performance.

Personnel HRM concept may increase the efficiency of HR professionals and the efficiency of HRM departments. HRM departments and professionals are important for implementing HRM in firms. For example, there may be specific specialists for employee affairs in HRM departments, and for other activities of HRM. For example, Society for Human Resource Management (SHRM), USA, focuses its activities on increasing the competency of HR professionals in USA.

\section{Analysis: New Paradigm of HRM - Personnel Efficiency}

This study discusses a new perspective for HRM. It is "task performance”. Personnel efficiency may be achieved through task performance. Task performance might be related with the competence of employees. For example, SHRM implements programs in order to increase the competence of HR professionals. Competence might be related with theoretical knowledge and task performance.

\section{New Role of Employee}

It is assumed that personnel management is related with organizational jobs. The responsibility of personnel is to achieve organizational jobs. HRM is in favor of increasing the efficiency of personnel in job. Therefore, PM focuses on jobs, and HRM focuses on efficiency. This study focuses on personnel efficiency and task performance.

The competence of employees increases the task performance of employees. For competence, employees (professionals) must have theoretical knowledge in their business field. For example, HR professionals must have HRM-related theoretical knowledge for competence, for task performance, and for personnel efficiency. On this matter, SHRM carries certification programs and annual conferences. The objective of HRM is to have an impact on organizational performance (Wright \& McMahan, 1992). It is assumed that if professionals are competent, organizational performance might increase. Assumption of this study is that: Professionals must have theoretical knowledge in their field to effectively implement their jobs. That might increase their task performance.

\section{Conclusion}

Personnel HRM may classify organization of HRM department, and it may increase the efficiency of HRM. This new perspective may be called as P-HRM.

\section{References}

Boston Consulting Group. (2010). Report on innovation 2010: A return to prominence and the emergence of the new world order. Wright, P. M., \& McMahan, G. C. (1992). Theoretical perspectives for strategic human resource management. Journal of Management, 18(2), 295-320. 